\title{
Karakterisasi dan Kinerja Membran Polyethersulfone Termodifikasi Aditif Anorganik secara Blending Polimer
}

\author{
Umi Fathanah $^{1^{*}}$, Hesti Meilina ${ }^{2}$ \\ ${ }^{1,2}$ Jurusan Teknik Kimia, Universitas Syiah Kuala \\ *Koresponden email: umifathanah@unsyiah.ac.id
}

Diterima: 11September 2021

Disetujui: 27 Oktober 2021

\begin{abstract}
Recently, membrane technology has developed rapidly as a process for water treatment. The membrane process is in demand due to several advantages including being able to work at low temperatures, easier to operate and easy to scale up. Magnesium hydroxide $\left(\mathrm{Mg}(\mathrm{OH})_{2}\right)$ is an inorganic compound that is inexpensive, non-toxic and hydrophilic, so it has the potential to be used as an additive in membrane fabrication. This study aims to determine the characteristics and performance (permeability and selectivity) of Polyethersulfone (PES) membrane modified with $\mathrm{Mg}(\mathrm{OH})_{2}$, using dimethyl Acetamide (DMAc) as solvent. The membrane was made by blending polymer with phase inversion technique and the characterization carried out included membrane morphological tests, functional group tests, water contact angle tests and evaluating membrane performance by measuring membrane selectivity and permeability. The results showed that the hydroxyl group contained in $\operatorname{Mg}(\mathrm{OH})_{2}$ was able to increase the hydrophilicity which was indicated by a decrease in the water contact angle on the modified membrane to $65^{\circ}$. The $\mathrm{Mg}(\mathrm{OH})_{2}$ additive acts as a pore-forming agent which can be seen in the changes in membrane morphology on the cross-section of the membrane surface. The performance of the membrane resulted in an increase in membrane permeability of $51 \mathrm{~L} / \mathrm{m}^{2}$.hour.bar with humid acid rejection of $63 \%$.
\end{abstract}

Keywords: PES, permeability, rejection, $\mathrm{Mg}(\mathrm{OH})_{2}$, hydrophilicity

\begin{abstract}
Abstrak
Dewasa ini teknologi membran telah berkembang pesat sebagai alternatif untuk proses pengolahan air. Proses membran diminati karena adanya beberapa keunggulan diantaranya dapat bekerja pada temperatur rendah, lebih mudah dalam pengoperasiannya serta mudah di scale up. $\left(\mathrm{Mg}(\mathrm{OH})_{2}\right)$ merupakan senyawa anorganik yang murah, non toxic dan bersifat hidrofilik sehingga berpotensi dijadikan sebagai aditif dalam pembuatan membran. Tujuan penelitian adalah untuk mengetahui karakteristik dan kinerja (permeabilitas dan selektivitas) membran Polyethersulfone (PES) termodifikasi $\mathrm{Mg}(\mathrm{OH})_{2}$, dengan dimethyl acetamide (DMAc) sebagai pelarut. Pembuatan membran dilakukan secara blending polimer dengan teknik inversi fasa. Karakterisasi membran yang dilakukan meliputi uji morfologi membran, uji gugus fungsi, uji sudut kontak air serta mengevaluasi kinerja membran melalui pengukuran permeabilitas dan selektivitas membran. Hasil penelitian menunjukkan bahwa gugus hidroksil yang terkandung dalam $\operatorname{Mg}(\mathrm{OH})_{2}$ mampu meningkatkan sifat hidrofilisitas yang ditandai dengan penurunan sudut kontak air pada membran yang dimodifikasi hingga $65^{\circ}$. Aditif $\mathrm{Mg}(\mathrm{OH})_{2}$ berperan sebagai agent pembentuk pori yang dapat dilihat pada perubahan morfologi membran pada penampang permukaan membran. Kinerja membran menghasilkan peningkatan permeabilitas membran sebesar $51 \mathrm{~L} / \mathrm{m}^{2}$.jam.bar dengan rejeksi asam humus sebesar $63 \%$.
\end{abstract}

Kata Kunci: PES, permeabilitas, rejeksi, $\mathrm{Mg}(\mathrm{OH})_{2}$, hidrofilisitas

\section{Pendahuluan}

Teknologi membran dalam pengolahan air telah dikenal sebagai teknologi alternatif yang dapat menggantikan proses pengolahan secara konvensional. Teknologi pemisahan menggunakan membran memiliki beberapa keuntungan diantaranya lebih mudah/sederhana, rendah biaya operasional maupun pemeliharaan alat, layout lebih kecil, temperatur operasi bekerja pada suhu ruang. Selain itu, proses pemisahan menggunakan membran dianggap sebagai proses yang efektif untuk memproduksi air bersih karena dapat menghilangkan tingkat kekeruhan air yang cukup tinggi, serta mampu merejeksi bakteri patogen sampai $100 \%[1]$.

Proses membran merupakan proses pemisahan berbasis membran yang telah diaplikasikan dalam industri seperti proses pengolahan air limbah, pengolahan makanan, bioseparasi serta manufaktur bidang farmasi [2]. Proses membran memberikan peran dengan standar kinerja yang tinggi, fluks tinggi, selektifitas tinggi fouling rendah, sehingga membran ultrafiltrasi telah menarik perhatian yang cukup tinggi dari para 
peneliti [3]. Namun dalam proses penggunaannya membran yang dipreparasi dari bahan polimer murni belum dapat meningkatkan kinerja membran. Sehingga sangat penting untuk menggabungkan polimer dan senyawa anorganik dalam membran hybrid untuk menghasilkan selektivitas dan permeabilitas yang menguntungkan [4].

Penggunaan bahan anoganik sebagai bahan aditif dalam membran polimer dengan tujuan untuk pembuatan membran hibrid seperti nanotube, $\mathrm{Fe}_{2} \mathrm{O}_{3}, \mathrm{TiO}_{2}, \mathrm{ZnO}, \mathrm{Al}_{2} \mathrm{O}_{3}$, dan $\mathrm{SiO}_{2}$ telah dilaporkan oleh sejumlah peneliti, dimana $\mathrm{SiO}_{2}$ merupakan bahan anorganik yang paling mudah dan telah banyak digunakan [5], [6], [7], [8]. Magnesium hydroxide dengan rumus kimia $\mathrm{Mg}(\mathrm{OH})_{2}$ adalah bahan anorganik yang tidak beracun, tidak korosif, yang secara termal bersifat tahan api yang stabil dan ramah lingkungan. Selain itu, $\operatorname{Mg}(\mathrm{OH})_{2}$ dapat digunakan pada temperatur pemrosesan yang lebih tinggi dari aluminium yang paling banyak digunakan untuk pengisi trihidrat. Dalam dekade terakhir, $\operatorname{Mg}(\mathrm{OH})_{2}$ telah banyak diminati $\mathrm{Mg}(\mathrm{OH})_{2}$ yang digunakan sebagai aditif tahan api untuk pembuatan bahan termoplastik tahan api [9],[10]. $\mathrm{Mg}(\mathrm{OH})_{2}$ juga digunakan sebagai penetral dalam pengolahan senyawa asam dari air limbah serta gas yang banyak mengandung oksida sulfur [11]. Selain itu $\mathrm{Mg}(\mathrm{OH})_{2}$ juga digunakan sebagai antasida excipient dalam obat-obatan [12]. $\mathrm{Mg}(\mathrm{OH})_{2}$ merupakan salah satu bahan anorganik yang secara umum dikenal dengan kelompok hidroksil $(\mathrm{OH})$ struktural yang signifikan sehingga sangat menarik perhatian peneliti [13]. Berdasarkan sifat hidrofilisitasnya, sifat antibakteri dan ramah lingkungan maka $\mathrm{Mg}(\mathrm{OH})_{2}$ dapat digunakan sebagai bahan untuk pembuatan membran [14], [15].

Dalam makalah ini, senyawa anorganik $\mathrm{Mg}(\mathrm{OH})_{2}$ digunakan sebagai senyawa aditif pada proses pembuatan membran polyethersulfone (PES) yang bertujuan untuk meningkatkan sifat hidrofilisitas membran yang diaplikasikan untuk proses pengolahan air yang mengandung senyawa organik. Pengaruh penambahan $\operatorname{Mg}(\mathrm{OH})_{2}$ akan diinvestigasi terhadap karakteristik dan kinerja membran yang dihasilkan. Modifikasi membran dilakukan dengan teknik blending polimer dengan mencampurkan PES sebagai polimer utama dengan $\mathrm{Mg}(\mathrm{OH})_{2}$ dengan berbagai variasi konsentrasi menggunakan dimethyl acetamide (DMAc) sebagai pelarut. Karakterisasi membran dilakukan dengan mengevaluasi perubahan struktur morfologi membran, gugus fungsi serta water contact angel (sudut kontak air) pada membran. Kinerja membran dipelajari dengan mengukur permeabilitas dan selektifitas membran yang dihasilkan. Tujuan penelitian adalah untuk mempelajari pengaruh penambahan $\mathrm{Mg}(\mathrm{OH})_{2}$ sebagai aditif serta DMAc sebagai pelarut, terhadap karakteristik dan kinerja membran modifikasi yang dihasilkan.

\section{Metode Penelitian Alat dan Bahan}

Adapun bahan utama yang digunakan adalah PES (Ultrason, E6020, Merck) dijadikan sebagai polimer dasar, pelarut yang digunakan adalah DMAc (Merck), senyawa aditif anoranik $\mathrm{Mg}(\mathrm{OH})_{2}$ (Xinglu, Chemical Co), serta akuades sebagai non solvent (non pelarut). Asam humus digunakan sebagai model sampel senyawa organik dalam air, untuk uji rejeksi (selektifitas) menggunakan modul membran ultrafiltrasi tipe dead end.

\section{Prosedur}

\section{Pembuatan Membran}

Teknik pembuatan membran dilakukan dengan metode inversi fasa yaitu dengan mencampurkan $18 \%$ PES sebagai polimer utama dengan aditif $\mathrm{Mg}(\mathrm{OH})_{2}$ dengan penambahan $0,5 \%, 1 \%$ dan $2 \%$ berat total larutan, dilarutkan ke dalam pelarut DMAc, yang selanjutnya disebut sebagai larutan dope. Pengadukan larutan dope menggunakan magnetic stirrer dilakukan hingga dicapai larutan yang homogen. Untuk menghindari terjadi aglomerisasi, maka larutan dimasukkan ke dalam sonikator pada suhu ruang selama 60 menit. Tahap selanjutnya dilakukan pencetakan (casting) diatas plat kaca, menggunakan aplikator dengan mengatur ketebalan sekitar $256 \mu \mathrm{m}$. Selanjutnya lapisan tipis yang terbentuk dilakukan perendaman dalam bak koagulasi yang berisi akuades sebagai non pelarut. Kemudian lapisan tipis (membran) yang terbentuk disimpan dalam akuades, yang akan digunakan untuk karakterisasi dan uji filtrasi menggunakan modul membran ultrafiltrasi. Adapun komposisi larutan dope yang dipreparasi disajikan pada Tabel 1.

Tabel 1. Komposisi larutan dope membran

\begin{tabular}{cccc}
\hline PES $(\%)$ & $\mathrm{Mg}\left(\mathrm{OH}_{2}\right)(\%)$ & DMAc $(\%)$ & Kode Membran \\
\hline 18 & 0 & 82 & $\mathrm{~A}$ \\
18 & 0,5 & 81,5 & $\mathrm{~B}$ \\
18 & 1 & 81 & $\mathrm{C}$ \\
18 & 2 & 80 & $\mathrm{D}$ \\
\hline
\end{tabular}

Sumber: Hasil pengujian penelitian (2020). 


\section{Karakterisasi membran}

Gugus fungsi yang terdapat pada membran dianalisa menggunakan Fourier Transform Infra-Red Spectroscopy - Attenuated Total Reflectance instrument (Thermo Scientific iD5 ATR-Nicolet iS5 FTIR Spectrophotometer, Jepang). Selanjutnya struktur morfologi membran PES murni (membran A) dan membran modifikasi (membran B, C, dan D) dianalisa menggunakan scanning electron microscopy (FESEM, JSF-7500F, JEOL Co., Ltd., Japan). Sifat hidrofilik membran dievaluasi dengan mengukur sudut kontak air antara permukaan membran dan tetesan air menggunakan contact angle meter Drop Master 300, Kyowa Interface Science Co., Jepang.

\section{Kinerja Membran}

Modul membran tipe aliran dead end digunakan untuk uji kinerja membran. Evaluasi kinerja membran meliputi permeabilitas air murni, dan uji rejeksi (selektifitas) asam humus, sebagai model sampel kandungan senyawa organik dalam air. Permeabilitas adalah salah satu faktor untuk menunjukkan performa (kinerja) membran. Nilai permeabilitas $\left(\mathrm{L}_{\mathrm{p}}\right)$ dapat dihitung dari kemiringan (slope) dari kurva perubahan tekanan terhadap fluks. Semakin besar nilai koefisien permeabilitas maka akan semakin mudah solute yang dapat melewati membran, sehingga kemampuan membran untuk melewatkan air juga semakin besar pula. Koefisien permeabilitas dihitung menggunakan persamaan 1 [16].

$$
\mathrm{L}_{\mathrm{p}}=\frac{\mathrm{J}}{\Delta_{\mathrm{p}}}
$$

$\mathrm{J}$ adalah fluks air $\left(\mathrm{L} / \mathrm{m}^{2} . j \mathrm{jm}\right)$ dan $\Delta \mathrm{P}$ adalah perubahan tekanan (bar).

Sedangkan rejeksi (selektivitas) merupakan fraksi konsentrasi zat terlarut yang tidak mampu melewati membran. Persamaan 2 digunakan untuk menghitung rejeksi membran [16].

$$
\mathrm{R}=1-\frac{\mathrm{Cp}}{\mathrm{Cf}} \times 100 \%
$$

$\mathrm{R}$ merupakan koefisien rejeksi (\%), $\mathrm{C}_{\mathrm{p}}$ merupakan kandungan zat terlarut dalam permeat (mg) serta $\mathrm{C}_{\mathrm{f}}$ merupakan kandungan zat terlarut dalam umpan $(\mathrm{mg})$. Uji rejeksi (selektifitas) dilakukan dengan cara melewatkan larutan sampel asam humus pada konsentrasi 50 ppm yang dialirkan melewati modul membran ultrafiltrasi pada tekanan 1 bar dengan waktu selama 1 jam, dengan melakukan pengukuran permeat yang ditampung pada interval waktu 10 menit hingga diperoleh berat yang konstan.

\section{Hasil dan Pembahasan Analisa Gugus Fungsi}

FTIR Spectroscopy adalah suatu peralatan yang biasa digunakan dalam menganalisa suatu struktur kimia (gugus fungsi) pada permukaan suatu sampel yang didasarkan oleh suatu ikatan atau adanya interaksi molekul dalam suatu bahan baik berupa absorbansi atau transmittansi dari sinar infra merah (infra red) yang diserap atau dipantulkan pada suatu sampel. Adapun spektrum FTIR pada semua membran yang dihasilkan, disajikan pada Gambar 1. Pada gambar teridentifikasi adanya kelompok gugus $\mathrm{C}-\mathrm{H}$ aromatik, kelompok eter aromatik $(\mathrm{C}-\mathrm{O}-\mathrm{C})$, kelompok cincin aromatik $(\mathrm{C}=\mathrm{C})$ yang muncul masing-masing pada panjang gelombang $836 \mathrm{~cm}^{-1}, 1239 \mathrm{~cm}^{-1}$ dan $1485 \mathrm{~cm}^{-1}$. Sedangkan kelompok gugus sulfon $(\mathrm{O}=\mathrm{S}=\mathrm{O})$ muncul pada spektrum bilangan gelombang $1139 \mathrm{~cm}^{-1}$. Kelompok gugus sulfon yang hadir pada puncak bilangan gelombang tersebut adalah getaran atom dalam material yang merupakan ciri khas adanya PES.

Selanjutnya dapat dilihat juga bahwa, membran termodifikasi dengan penambahan aditif $\operatorname{Mg}(\mathrm{OH})_{2}$, (membran B, C dan D) yang ditunjukkan pada Gambar 1, menunjukkan adanya transmittansi yang muncul pada panjang gelombang $3696 \mathrm{~cm}^{-1}$ yang merupakan getaran atom gugus hidroksil (-OH) dari molekul air yang berasal dari $\mathrm{Mg}(\mathrm{OH})_{2}$. Hal ini membuktikan bahwa $\mathrm{Mg}(\mathrm{OH})_{2}$ berhasil ditambahkan ke dalam membran secara inversi fasa. Kehadiran gugus hidroksil $(-\mathrm{OH})$ pada serbuk magnesium hydroxide juga teridentifikasi pada bilangan gelombang 3699 dan $3697 \mathrm{~cm}^{-1}$ telah dilaporkan oleh peneliti terdahulu [17], [18]. Pada penelitian ini peregangan getaran gugus hidroksil (-OH) muncul pada panjang gelombang 3696 $\mathrm{cm}^{-1}$ terlihat pada membran hasil modifikasi (membran B, C dan D). Adanya spektrum yang muncul ini mengidentifikasikan bahwa blending $\mathrm{Mg}(\mathrm{OH})_{2}$ pada matrik membran PES berhasil dilakukan. 


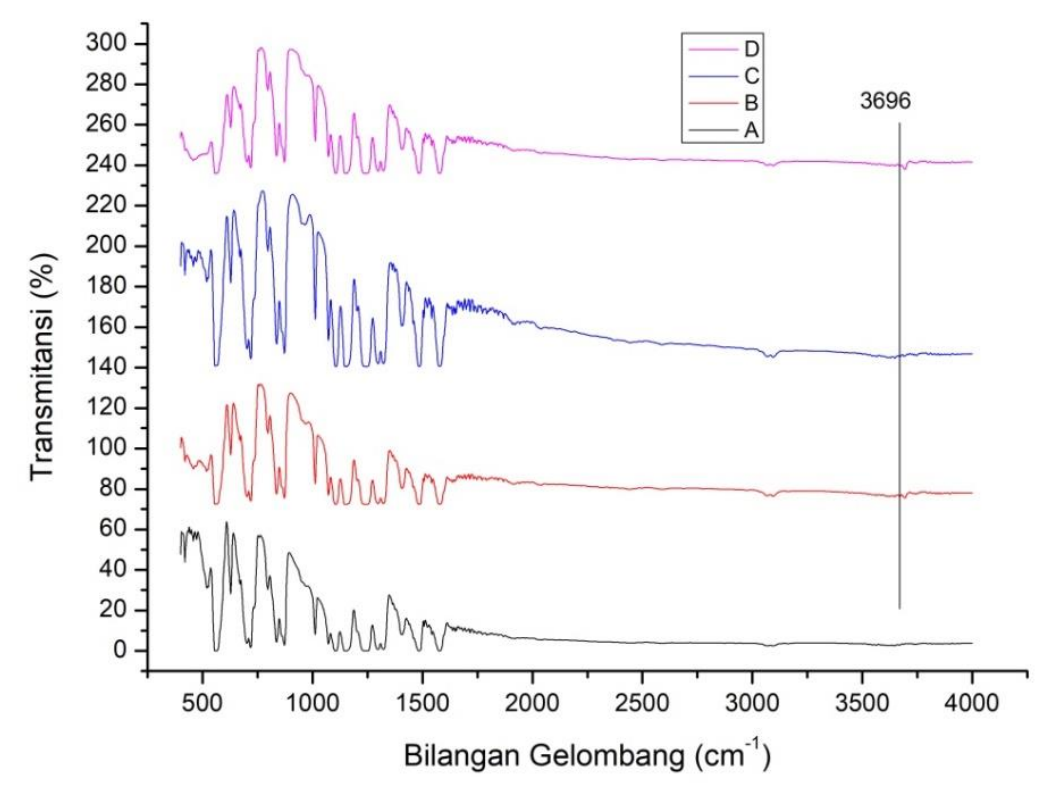

Gambar 1. Spektra FTIR pada membran Sumber: Hasil pengujian penelitian (2020)

\section{Morfologi Membran}

Analisis struktur morfologi membran dilakukan menggunakan SEM dengan tujuan untuk melihat perubahan morfologi membran yang terjadi pada permukaan membran sebelum dan setelah dimodifikasi dengan penambahan aditif $\mathrm{Mg}(\mathrm{OH})_{2}$. Pada Gambar 2a terlihat bahwa membran A menunjukkan pori yang terbentuk sangat dense, di mana keberadaan pori-pori yang terlihat sangat kecil dan sangat rapat. Ketika membran PES dimodifikasi dengan penambahan $\mathrm{Mg}(\mathrm{OH})_{2}$, terlihat perubahan terhadap keberadaan pori yang sangat signifikan. Pada membran D (Gambar 2b) terlihat dengan jelas munculnya pori-pori yang tersebar di permukaan membran. Hal ini menunjukkan, bahwa aditif $\mathrm{Mg}(\mathrm{OH})_{2}$ berperan sebagai agen pembentuk pori di dalam membran PES. Pori-pori yang terbentuk akibat penambahan $\operatorname{Mg}(\mathrm{OH})_{2}$ dapat mempercepat laju penetrasi air melewati membran [12].
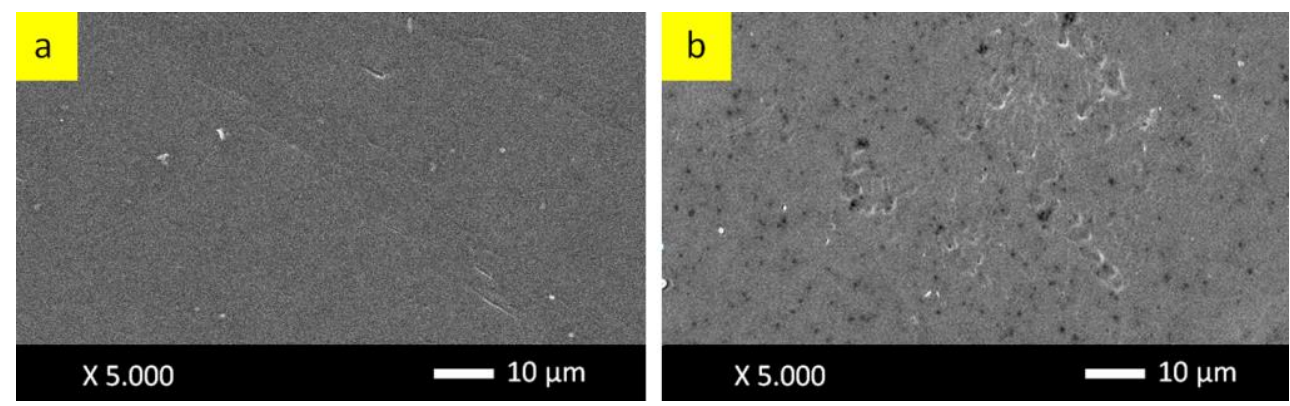
Gambar 2. Morfologi surface section (penampang permukaan) membran dengan perbesaran 5000 kali; (a)
Membran A; (b) Membran D

Sumber: Hasil pengujian penelitian (2020)

\section{Sifat Hidrofilisitas Membran}

Hidrofilisitas membran dapat ditentukan dengan mengukur sudut kontak air pada membran. Sudut kontak air menunjukkan derajat kebasahan pada permukaan membran. Suatu membran dinyatakan sebagai membran hidrofobik yaitu bila membran mempunyai sudut kontak air diatas $90^{\circ}$ yang artinya tetesan air tidak mampu menyebar diatas permukaan membran. Sedangkan membran dinyatakan sebagai membran hidrofilik, yaitu membran yang memiliki sudut kontak air di bawah $90^{\circ}$, artinya membran tersebut mampu menyerap tetesan air yang ada di permukaan membran [19].

Secara umum, modifikasi membran dengan penambahan aditif $\mathrm{Mg}(\mathrm{OH})_{2}$ menunjukkan penurunan nilai sudut kontak air, artinya semua membran yang dimodifikasi memiliki sifat hidrofilisitas yang semakin meningkat. Pada Gambar 3, menunjukkan bahwa nilai sudut kontak air pada membran A, B, C dan D masing-masing adalah sebesar $83^{\circ}, 77^{\circ}, 67^{\circ}$, dan $65^{\circ}$. Berdasarkan data tersebut jelas terlihat bahwa 
membran PES murni (membran A) memiliki sifat hidrofilisitas yang paling rendah dibandingkan dengan membran yang telah dimodifikasi. Penambahan aditif $\mathrm{Mg}(\mathrm{OH})_{2}$ pada membran PES dapat dinyatakan sebagai pore forming agent (agen pembentuk pori), yang dapat dilihat pada membran modifikasi jelas terlihat adanya pembentukan pori-pori di atas permukaan membran, yang dapat dikonfirmasi dari uji struktur morfologi menggunakan SEM (Gambar 2).

Selanjutnya adanya gugus hidroksil $(-\mathrm{OH})$ yang bersumber dari aditif $\mathrm{Mg}(\mathrm{OH})_{2}$, memberikan sumbangan sifat hidrofilik yang signifikan pada matrik membran PES, yang telah dijelaskan pada analisa gugus fungsi menggunakan FTIR (Gambar 1). Hal ini menjadi dugaan sebagai akibat terjadinya penurunan nilai sudut kontak air, atau dapat dinyatakan sifat hidrofilisitas membran yang dimodifikasi dengan penambahan $\mathrm{Mg}(\mathrm{OH})_{2}$ menjadi semakin meningkat. Temuan yang sama juga telah dinyatakan oleh peneliti terdahulu bahwa penambahan $\mathrm{Mg}(\mathrm{OH})_{2}$ pada membran polyvinylidene fluoride (PVDF) mampu menurunkan sudut kontak air membran atau dengan kata lain dapat meningkatkan sifat hidrofilisitas membran [12],[17].

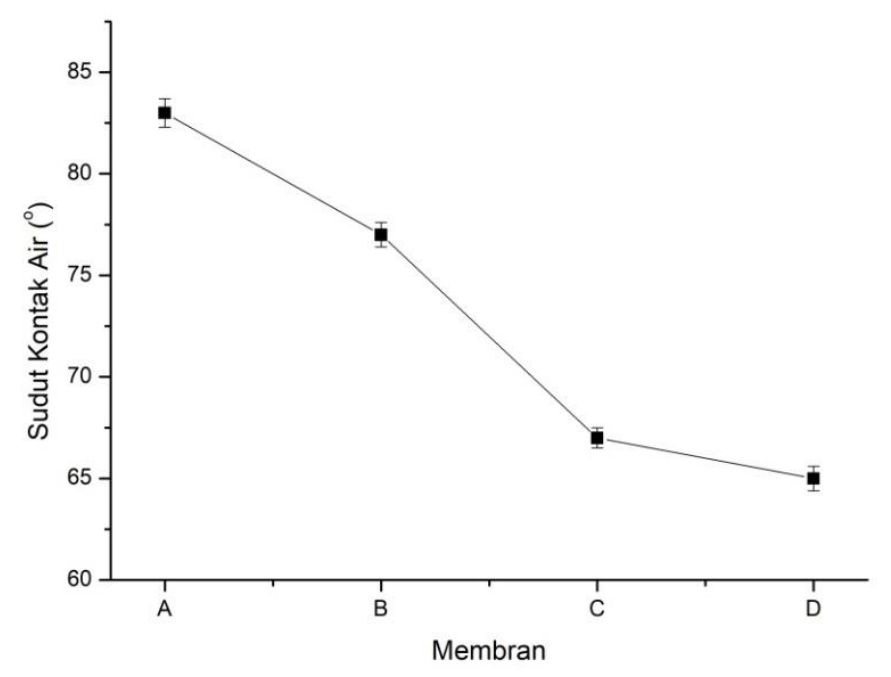

Gambar 3. Sudut kontak air pada membran Sumber: Hasil pengujian penelitian (2020)

\section{Kinerja Membran}

Parameter performa (kinerja) kinerja membran adalah permeabilitas dan rejeksi (selektivitas). Permeabilitas air adalah kemampuan membran untuk melewatkan spesi atau konstituen menembus lapisan membran. Sedangkan rejeksi atau selektifitas adalah ukuran kemampuan membran untuk menahan suatu spesi tertentu. Gambar 5 menunjukkan pengaruh penambahan $\mathrm{Mg}(\mathrm{OH})_{2}$ terhadap permeabilitas air. Penambahan $\mathrm{Mg}(\mathrm{OH})_{2}$ ke dalam larutan casting mampu meningkatkan permeabilitas air pada membran modifikasi yaitu membran B, C dan D masing-masing sebesar $22 \mathrm{~L} / \mathrm{m}^{2}$.jam.bar ; $35 \mathrm{~L} / \mathrm{m}^{2}$.jam.bar; dan 51 $\mathrm{L} / \mathrm{m}^{2}$.jam.bar. Sedangkan membran PES murni tanpa modifikasi (membran A) memiliki permeabilitas air murni yang paling rendah yaitu $5,2 \mathrm{~L} / \mathrm{m}^{2}$.jam.bar. Kenaikan permeabilitas air murni pada membran B, C dan $\mathrm{D}$ berkaitan dengan sifat hidrofilisitas membran yang dapat dikonfirmasi dengan penurunan sudut kontak air. Jelas bahwa sudut kontak air pada membran B, C dan D lebih rendah dari membran A, artinya hidrofilisitas membran mengalami peningkatan yang mengakibatkan permeabilitas air pada membran menjadi bertambah.

Peningkatan permeabilitas air juga dapat dilihat dari struktur morfologi membran. Struktur morfologi pada penampang pemukaan membran memperlihatkan munculnya pori-pori di sepanjang penampang membran modifikasi terlihat jelas, sedangkan membran tanpa modifikasi terlihat penampang membran yang sangat dense (rapat) (Gambar 4a). Dengan demikian sangat mungkin permeabilitas air membran modifikasi lebih besar dibandingkan membran PES murni tanpa modifikasi. Peningkatan nilai permeabilitas ini juga disebabkan karena dengan adanya penambahan zat aditif $\mathrm{Mg}(\mathrm{OH})_{2}$ yang membuat permukaan membran menjadi bersifat hidrofilik sehingga lebih mudah menyerap molekul air dan berakibat pada peningkatan jumlah air yang lolos dari membran. 
Selain itu peningkatan permeabilitas air pada membran yang dimodifikasi juga dapat diamati dengan kehadiran kelompok gugus hidroksil $(-\mathrm{OH})$ yang berasal dari $\mathrm{Mg}(\mathrm{OH})_{2}$ yang dapat dikonfirmasi dari analisa gugus fungsi menggunakan FTIR pada Gambar 1. Kemunculan kelompok hidroksil (-OH) yang bersifat hidrofilik dari kristal air pada $\mathrm{Mg}(\mathrm{OH})_{2}$, dikonfirmasi pada panjang gelombang $3696 \mathrm{~cm}^{-1}$, yang memungkinkan terjadinya peningkatan hidrofilisitas membran modifikasi. Hidrofilisitas permukaan membran dapat mempengaruhi permeabilitas membran [20]. Dilaporkan bahwa semua membran yang dimodifikasi dengan $\mathrm{Mg}(\mathrm{OH})_{2}$ memiliki nilai permeabilitas yang lebih tinggi dibandingkan membran tanpa modifikasi (membran A).

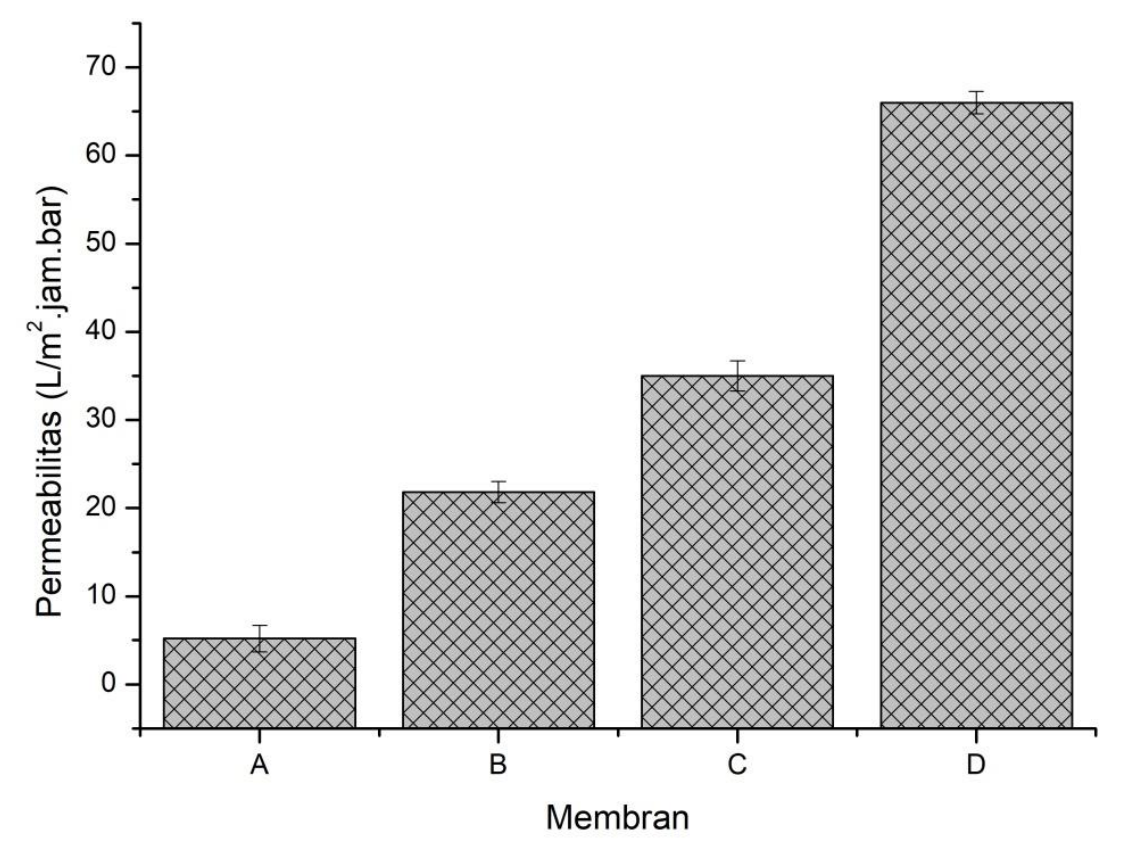

Gambar 4. Permeabilitas air pada berbagai jenis membran Sumber: Hasil pengujian penelitian (2020)

Pengujian kinerja membran juga dilakukan dengan menghitung besarnya persen rejeksi atau selektivitas terhadap asam humus sebagai sampel artificial untuk menghilangkan senyawa organik pada air. Asam humus yang dimaksud adalah fraksi zat humus yang terdapat di dalam tanah serta ikut terbawa di air permukaan dengan konsentrasi yang rendah, yang merupakan hasil dekomposisi protein, karbohidrat dan lignin [16]. Uji rejeksi membran dilakukan dengan menggunakan seperangkat modul filtrasi dengan aliran dead end, dengan melewatkan 50 ppm asam humus selama 30 menit pada tekanan 1 bar. Selanjutnya dilakukan pengukuran nilai fluks yang diperoleh dan dilakukan analisa konsentrasi permeat dan retentat menggunakan spektrofotometer $U V$-Visible Spectrophotometer.

Gambar 4 memperlihatkan performa rejeksi membran terhadap rejeksi asam humus. Rejeksi membran memiliki kecenderungan mengalami penurunan dengan adanya penambahan konsentrasi $\mathrm{Mg}(\mathrm{OH})_{2}$. Penurunan koefisien rejeksi membran dapat dilihat pada membran A, B, C dan D yaitu masingmasing sebesar $72 \%, 68 \%, 65 \%$ dan 63\%. Seperti telah dijelaskan sebelumnya, bahwa sifat hidrofilisitas membran meningkat dengan meningkatnya penambahan konsentrasi $\mathrm{Mg}(\mathrm{OH})_{2}$. Peningkatan sifat hidrofilisitas permukaan membran ini akan menghambat interaksi dengan molekul hidrofobik asam humus. Hal ini menyebabkan rejeksi membran menjadi menurun. 


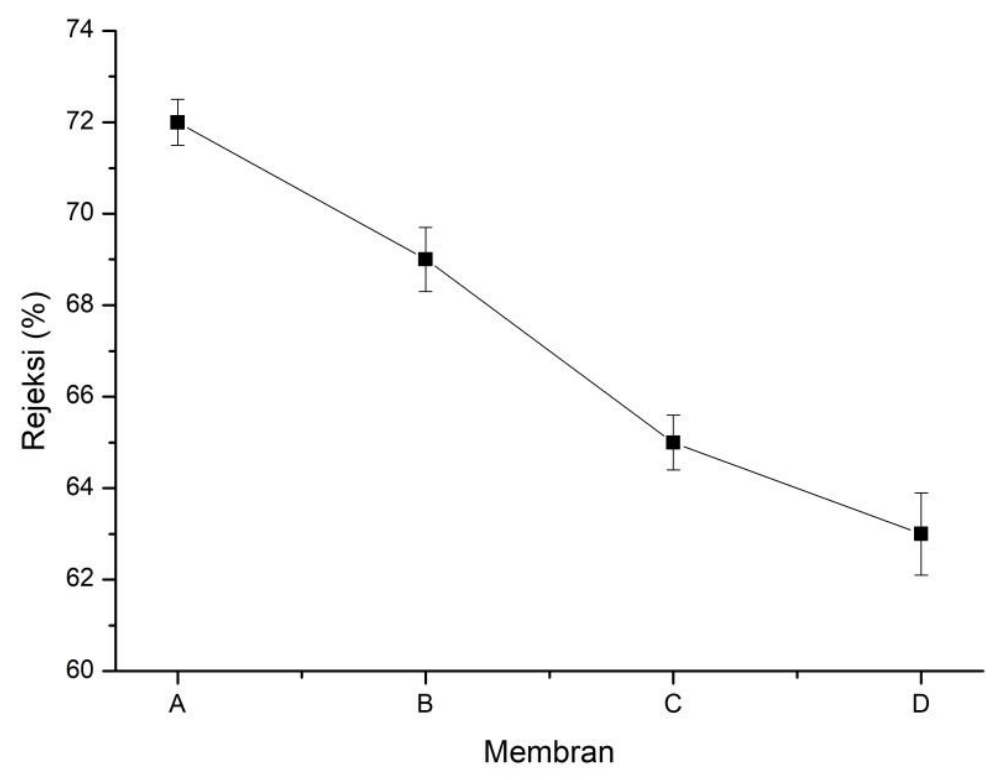

Gambar 5. Rejeksi pada berbagai jenis membran Sumber: Hasil pengujian penelitian (2020)

\section{Kesimpulan}

Membran PES yang dimodifikasi dengan penambahan aditif $\mathrm{Mg}(\mathrm{OH})_{2}$ menunjukkan perubahan struktur morfologi dan kinerja membran. Hasil karakterisasi menunjukkan bahwa adanya kehadiran kelompok hidroksil (-OH) dari $\mathrm{Mg}(\mathrm{OH})_{2}$ yang menunjukkan interaksi antara polimer PES dan $\mathrm{Mg}(\mathrm{OH})_{2}$ dilihat dari analisa menggunakan FTIR, yang menyebabkan sifat hidrofilisitas membran meningkat. Peningkatan sifat hidrofilisitas ini juga dapat dikonfirmasi dengan penurunan water contact angle pada membran yang dimodifikasi dengan $\mathrm{Mg}(\mathrm{OH})_{2}$. Karakterisasi membran menggunakan SEM menunjukkan bahwa membran yang dimodifikasi dengan $\mathrm{Mg}(\mathrm{OH})_{2}$, memperlihatkan sebaran pori-pori di sepanjang luas penampang membran, sehingga $\mathrm{Mg}(\mathrm{OH})_{2}$ dapat berperan sebagai pore forming agent. Sedangkan kinerja membran yang dimodifikasi memberikan nilai permeabilitas tertinggi pada membran PES yang dimodifikasi yaitu dengan penambahan $2 \% \mathrm{Mg}(\mathrm{OH})_{2}$ dengan nilai sebesar $51 \mathrm{~L} / \mathrm{m}^{2}$.h.bar dan koefisien rejeksi sebesar $63 \%$.

\section{Daftar Pustaka}

[1] R. J. Gohari, E. Halakoo, N. A. M. Nazri, W. J. Lau, T. Matsuura, and A. F. Ismail, "Improving performance and antifouling capability of PES UF membranes via blending with highly hydrophilic hydrous manganese dioxide nanoparticles," $D E S$, vol. 335, no. 1, pp. 87-95, 2014, doi: 10.1016/j.desal.2013.12.011.

[2] C. Nie, "Novel heparin-mimicking polymer brush grafted carbon nanotube / PES composite membranes for safe and efficient blood purification," J. Memb. Sci., vol. 475, pp. 455-468, 2015, doi: 10.1016/j.memsci.2014.11.005.

[3] H. Susanto and M. Ulbricht, "Characteristics, performance and stability of polyethersulfone ultrafiltration membranes prepared by phase separation method using different macromolecular additives," J. Memb. Sci., vol. 327, pp. 125-135, 2009, doi: 10.1016/j.memsci.2008.11.025.

[4] Z. Xu, L. Yu, and L. Han, "Polymer-nanoinorganic particles composite membranes: a brief overview," vol. 3, no. 3, pp. 318-329, 2009, doi: 10.1007/s11705-009-0199-0.

[5] M. Y. Wahab, "Synergistic effects of organic and inorganic additives in preparation of composite poly (vinylidene fluoride) antifouling ultrafiltration membranes," J. Appl. Polym. Sci., vol. 0, no. 0, p. 47737, Mar. 2019, doi: 10.1002/app.47737.

[6] X. Li, "Self-assembly of $\mathrm{TiO} 2$ nanoparticles around the pores of PES ultrafiltration membrane for mitigating organic fouling," J. Memb. Sci., vol. 467, pp. 226-235, 2014, doi: 10.1016/j.memsci.2014.05.036.

[7] A. Ahmad, I. Afzal, M. Irfan, C. Lee, and J. Kim, "Optimization of membrane modification using $\mathrm{SiO} 2$ for robust anti-fouling performance with calcium-humic acid feed in membrane distillation," 
Environ. Res., vol. 170, no. September 2018, pp. 374-382, 2019, doi: 10.1016/j.envres.2018.12.036.

[8] S. Mulyati, "Production of High Flux Poly (Ether Sulfone) Membrane Using Silica Additive Extracted from Natural Resource," Membranes (Basel)., vol. 10, no. 1, p. 17, 2020, doi: 10.3390/membranes 10010017.

[9] J. Hsu and A. Nacu, "Preparation of submicron-sized $\mathrm{Mg}(\mathrm{OH}) 2$ particles through precipitation," vol. 262, no. October 2004, pp. 220-231, 2005, doi: 10.1016/j.colsurfa.2005.04.038.

[10] H. Wu, M. Shao, J. Gu, and X. Wei, "Microwave-assisted synthesis of fibre-like Mg ( OH ) 2 nanoparticles in aqueous solution at room temperature," vol. 58, pp. 2166-2169, 2004, doi: 10.1016/j.matlet.2004.01.010.

[11] A. A. Pilarska, Ł. Klapiszewski, and T. Jesionowski, "Recent development in the synthesis, modification and application of $\mathrm{Mg}(\mathrm{OH}) 2$ and MgO: A review," Powder Technol., vol. 319, pp. 373407, 2017, doi: 10.1016/j.powtec.2017.07.009.

[12] S. Han, L. Mao, T. Wu, and H. Wang, "Homogeneous polyethersulfone hybrid membranes prepared with in-suit synthesized magnesium hydroxide nanoparticles by phase inversion method," J. Memb. Sci., vol. 516, pp. 47-55, 2016, doi: 10.1016/j.memsci.2016.05.040.

[13] P. T. Jochym, A. M. Ole, K. Parlinski, J. Ła, P. Piekarz, and M. Sternik, "Structure and elastic properties of $\mathrm{Mg}(\mathrm{OH}) 2$ from density functional theory," J. Phisics Condens. Matter, vol. 445403, 2010, doi: 10.1088/0953-8984/22/44/445403.

[14] C. Dong, D. Song, J. Cairney, O. Lee, G. He, and Y. Deng, "Antibacterial study of Mg (OH) 2 nanoplatelets," Mater. Res. Bull., vol. 46, no. 4, pp. 576-582, 2011, doi: 10.1016/j.materresbull.2010.12.023.

[15] U. Fathanah et al., "Enhancement of Antifouling of Ultrafiltration Polyethersulfone Membrane with Hybrid Mg $(\mathrm{OH}) 2$ / Chitosan by Polymer Blending Graphical abstract Keywords," vol. 6, pp. 375382, 2020, doi: 10.22079/JMSR.2020.124107.1365.

[16] S. R. Panda, M. Mukherjee, and S. De, "Journal of Water Process Engineering Preparation, characterization and humic acid removal capacity of chitosan coated iron-oxide- polyacrylonitrile mixed matrix membrane," J. Water Process Eng., vol. 6, pp. 93-104, 2015, doi: 10.1016/j.jwpe.2015.03.007.

[17] C. Dong, G. He, H. Li, R. Zhao, Y. Han, and Y. Deng, "Antifouling enhancement of poly (vinylidene fluoride) microfiltration membrane by adding $\mathrm{Mg}(\mathrm{OH}) 2$ nanoparticles," J. Memb. Sci., vol. 387-388, no. 1, pp. 40-47, 2012, doi: 10.1016/j.memsci.2011.10.007.

[18] C. Dong, Y. Dai, S. Jiang, and G. He, "Application of $\mathrm{Mg}(\mathrm{OH})$ 2nanoplatelets as pore former to prepare PVDF ultrafiltration membranes," J. Environ. Chem. Eng., vol. 5, no. 1, pp. 877-883, 2017, doi: 10.1016/j.jece.2017.01.006.

[19] J. H. Jhaveri and Z. V. P. Murthy, "A comprehensive review on anti-fouling nanocomposite membranes for pressure driven membrane separation processes," Desalination, vol. 379, pp. 137154, 2016, doi: 10.1016/j.desal.2015.11.009.

[20] E. Saljoughi and S. M. Mousavi, "Preparation and characterization of novel polysulfone nanofiltration membranes for removal of cadmium from contaminated water," Sep. Purif. Technol., vol. 90, pp. 22-30, 2012, doi: 10.1016/j.seppur.2012.02.008. 